\title{
Formula aequalitas na actividade administrativa
}

\author{
Formula aequalitas in administrative activity
}

Ana Cristina Martins Roso ${ }^{1}$ Email: ana.roso@gmail.com Docente do Instituto Superior de Contabilidade e Administração de Coimbra

Doutorada em Direito Público e Mestre na área do Direito

Administrativo pela

Faculdade de Direito da Universidade de Coimbra
Resumo: Pretende-se analisar o princípio da igualdade na actividade administrativa, daí o título do nosso artigo: "Formula aequalitas na actividade administrativa”. Começar por referir que o princípio da igualdade, que se encontra previsto no artigo $13 .^{\circ}$ da Constituição da República Portuguesa, é um dos princípios estruturantes do Estado de Direito Democrático e Social. Sendo também um dos princípios fundamentais materiais da actividade administrativa, nos termos do artigo 6. ${ }^{\circ}$ do novo Código do Procedimento Administrativo (corresponde ao artigo 5..$^{\circ}$ do antigo Código do Procedimento Administrativo). Propomonos, depois de analisar a sua importância e consagração na Lei Fundamental, irmos verificar da importância que vem assumindo o princípio da igualdade no seio da actividade administrativa.

Palavra-chave: Princípio da igualdade. Princípio de Estado de Direito Democrático e Social. Actividade administrativa. Princípio fundamental da actividade administrativa.

Abstract: It is intended to analyze the principle of equality in
administrative activity, hence the title of our article: "Formula aequalitas
in administrative activity". It should be noted that the principle of equality,
which is laid down in Article 13 of the Constitution of the Portuguese
Republic, is one of the structuring principles of the rule of democratic and
social law. It is also one of the basic material principles of administrative
activity, in accordance with Article 6 of the new Code of Administrative
Procedure (corresponds to Article 5 of the former Code of Administrative
Procedure). We propose, after analyzing its importance and consecration
in the Basic Law, to verify the importance of the principle of equality in
administrative activity.

Keyword: Principle of equality. Principle of State of Democratic and Social Law. Administrative activity. Basic principle of administrative activity. 


\section{pontěditora}

\section{Introdução}

Este ensaio corresponde a uma adaptação e actualização de uma investigação realizada no âmbito da cadeira de Jurisprudência de Direito Administrativo, do $2 .^{\circ}$ Ciclo de Estudos da Faculdade de Direito da Universidade de Coimbra, no passado ano lectivo de 2007/2008. Este trabalho centra-se no princípio da igualdade, que é um dos princípios fundamentais materiais da actividade administrativa.

O princípio da igualdade é um dos princípios estruturantes do Estado de Direito Democrático e Social. Marcando presença em textos constitucionais desde há dois séculos, este princípio esteve exposto a uma grande evolução ao longo deste tempo. É um princípio teoricamente complexo e de aplicação prática extremamente difícil. No entanto, é portador de um significado, rico, fascinante e simbólico, falar de igualdade é falar da própria dignidade humana e do próprio princípio de justiça, (o símbolo do Direito é uma pessoa do sexo feminino de olhos vendados, com uma balança numa das mãos e na outra uma espada, a balança pretende significar igualdade).

Propomo-nos fazer uma breve explanação pela consagração constitucional do princípio da igualdade, para em seguida passar a uma análise doutrinal e legal da consagração do mesmo no (novo) Código de Procedimento Administrativo. De notar que quando foi feita a investigação inicial (durante o nosso mestrado) que levaria à redacção do presente artigo (ano lectivo 20072008) vigorava o anterior Código do Procedimento Administrativo, que havia sido aprovado pelo Decreto-Lei n. ${ }^{\circ}$ 442/91, de 15 de novembro, o qual sofreu várias alterações, até ser revogado pelo Decreto-Lei n. ${ }^{\circ} 4 / 2015$, de 07 de Janeiro, que aprovou o novo Código do Procedimento Administrativo (doravante CPA), daí a necessidade de agora proceder à actualização do presente artigo (conforme referido supra).

\section{O Princípio da igualdade e o constitucionalismo}

Falar no princípio da igualdade é, antes de mais, falar em princípios jurídicos, mas o que se entende por princípio?

O Princípio "traduz um sentido do direito, um vector que informa o conteúdo das normas, orientando o legislador e o intérprete, mas que pode, em determinadas condições ser directamente aplicada a casos concretos. Induz-se de fontes e normas pela construção e 


\section{pontěditora}

sistematização científica" ${ }^{\text {. }}$.

Avancemos, então agora, com uma noção de princípio da igualdade (jurídica), "o seu sentido primário ou negativo consiste na proibição de privilégios e de discriminações (...) Destinatários do princípio vêm a ser, desde logo, os órgãos de criação. Igualdade significa hoje, antes de mais, criação de lei igual para todos. Mas este princípio significa, talvez, ainda mais aplicação igual da lei, os seus destinatários são tanto os tribunais como os órgãos e agentes administrativos"6.

O princípio da igualdade é um dos princípios estruturantes do sistema constitucional global, harmonizando no seu conteúdo as dimensões liberais, democráticas e sociais, dimensões que são inerentes ao próprio conceito de Estado de Direito democrático e social (artigo $2 .^{\circ}$ da Constituição da Republica Portuguesa, CRP).

Mas este princípio tal como hoje o conhecemos, é o produto de uma longa evolução.

A igualdade assim como a liberdade adquiriram com as Revoluções Liberais, um sentido fundamentante e estruturante da vida político-social. A vontade de garantir a sua concretização era tão grande nesta época, que fez emergir vários documentos formais de natureza especiais: as Declarações de Direitos e, em particular, as Constituições escritas. A igualdade dos homens foi, pela primeira vez, consagrada juridicamente, na América, na Virginia Bill of Rights, em 12 de Junho de 1776, onde se reconheceu que "todos os homens são por natureza igualmente livres e independentes e têm certos direitos inerentes", tendo sido retomada, também na América, na Constituição de Massachussets, de 2 de Março de 1780, onde se consagrou que, "todos os homens nasceram livres e iguais, e têm certos direitos naturais, essenciais e inalienáveis", depois em França numa formulação mais clara, na 1. "Declaração dos Direitos do Homem e do Cidadão", em 1789, onde se prevê que, "os homens nascem e são livres e iguais em direitos"7.

Estes textos prepararam o hoje "clássico" enunciado do princípio da igualdade perante a lei,

\footnotetext{
${ }^{5}$ João Melo Franco e António Herlander Antunes Martins, "Dicionário de Conceitos e Princípios Jurídicos: na Doutrina e na Jurisprudência”, 3. ' Edição, Almedina, 1993, pág. 689.

6 Idem, pág. 693.

7 Como vimos, foi na América que pela primeira os textos básicos consagraram pela primeira vez constitucionalmente a igualdade. Assim, não coube à França (como muitos ainda hoje erroneamente pensam) esta glória. Coube-lhe, apenas, sim o enunciado que, por ser o mais conhecido, se tornou o mais influente. Vide Martim de Albuquerque, “Da Igualdade - Introdução à Jurisprudência”, Livraria Almedina, Coimbra, 2003, pág. 45 47.
} 


\section{pontěditora}

consagrada na Declaração dos Direitos do Homem e do Cidadão, de França em 1793, "[t]odos os homens são iguais por natureza e diante da lei”. A partir de então, este princípio foi adquirido como um verdadeiro axioma jurídico de todas as Constituições, até aos nossos dias. Também, as Constituições Portuguesas, do século XIX (Constituição de 1822, Carta Constitucional de 1826 e Constituição de 1838), influenciadas pela ideologia saída das Revoluções Americana e Francesa, já consagravam o princípio da igualdade ${ }^{8}$.

Muitos foram os textos constitucionais e as Declarações de Direitos que se seguiram ao supra exposto, mas devido à sua importância não podemos deixar de referenciar aqui o $\operatorname{artigo~} 1^{\circ}$, da Declaração Universal dos Direitos do Homem, adoptada e proclamada pela resolução 217 A (III) da Assembleia Geral das Nações Unidas em 10 de Dezembro de 1948, cujas palavras, nunca são de mais relembrar: "Todos os seres humanos nascem livres e iguais em dignidade e direitos. Dotados de razão e de consciência, devem agir uns para com os outros em espírito de fraternidade" 9 .

\subsection{O princípio da igualdade e o artigo $13 .^{\circ}$ da CRP}

A Constituição Portuguesa de 1976 consagra o princípio da igualdade no seu artigo 13. ${ }^{\circ}$, onde podemos ler no n. ${ }^{\circ} 1$, "[t] odos os cidadãos têm a mesma dignidade social e são iguais perante a lei”, e no n. 2 , “[n]inguém pode ser privilegiado, beneficiado, prejudicado, privado de qualquer direito ou isento de qualquer dever em razão da ascendência, sexo, raça, língua, território de origem, religião, convicções politicas ou ideológicas, instrução, situação económica, condição social ou orientação sexual".

Este princípio será, eventualmente, o mais antigo com consagração constitucional, essa longevidade constitucional fê-lo experimentar, como já referimos, uma evolução acentuada e multifacetada. Como ele é actualmente entendido na generalidade dos Estados democráticos, consegue conciliar dialecticamente diferentes dimensões. No entanto, continua a abrir-se a novas e discutíveis utilizações que o tornam num princípio sempre aberto, controverso e de compreensão não tão linear quanto uma evolução "refinada" ao longo dos tempos podia fazer

\footnotetext{
${ }^{8}$ Maria Glória F.P.D. Garcia, “Estudos sobre o Princípio da Igualdade”, Almedina, 2005, pág. 31.

${ }^{9}$ Idem, pág. 8.
} 


\section{pontěditora}

esperar $^{10}$.

Este princípio é, pois, uma síntese dialéctica entre três diferentes dimensões: uma dimensão liberal, na qual o princípio da igualdade fornece a ideia de igualdade de todas as pessoas, independentemente do seu nascimento e do seu status, perante a lei, que é geral e abstracta, considerada subjectivamente universal em virtude da sua impessoalidade e da aplicação a um número indeterminável de casos. Uma dimensão democrática que exige uma proibição de discriminações, quer seja no acesso e participação no exercício do poder político e também no acesso a cargos públicos. Por último, uma dimensão social, na qual se salienta a função social do princípio da igualdade, impondo a eliminação das desigualdades fácticas (sociais, económicas e culturais), para que assim se possa alcançar a "igualdade real entre portugueses" $"$.

A base constitucional do princípio da igualdade é a igual dignidade social de todos os cidadãos (n. ${ }^{\circ} 1$ do artigo $13 .^{\circ}$ da CRP), que mais não é do que um corolário da igual dignidade de todas as pessoas.

$\mathrm{Na} 2 .^{\circ}$ parte, do.$^{\circ} 1$, do artigo $13^{\circ}$, da CRP ao determinar-se $\boldsymbol{a}$ igualdade dos cidadãos perante $\boldsymbol{a} \boldsymbol{l e i}$, acolhe-se a versão adquirida da fórmula clássica do princípio da igualdade com que se colocou fim às desigualdades de nascimento e de estatuto jurídico no "antigo regime". No fundo, este princípio trata da igualdade de todos em matéria de direitos e deveres, todos devem beneficiar de direitos e vantagens, e todos devem suportar deveres e encargos.

"A igualdade desdobra-se em duas proibições e uma obrigação - proibição de arbítrio, proibição de discriminação e obrigação de diferenciação" ${ }^{12}$.

A proibição do arbítrio, traduz-se num limite externo da liberdade de conformação ou de decisão dos poderes públicos, serve aqui este princípio como princípio negativo de controlo: nem aquilo que é essencialmente igual deve ser tratado arbitrariamente (sem fundamentação, ou com uma justificação insuficiente) como desigual, nem o fundamentalmente desigual deve ser de modo arbitrário tratado como igual. Assim, este princípio significa que positivamente é

\footnotetext{
${ }^{10}$ Jorge Reis Novais, “Os Princípios Constitucionais Estruturantes da República Portuguesa”, Coimbra Editora, 2004, pág.101.

${ }^{11}$ J.J. Gomes Canotilho e Vital Moreira, "Constituição da República Portuguesa Anotada", Vol. I, 4. Edição Revista, 2007, anotação ao artigo ${ }^{\circ} 13$, pág. 337.

${ }^{12}$ Martim de Albuquerque, "Da Igualdade", cit., pág. 334-337, e Gomes Canotilho e Vital Moreira, "Constituição Anotada", Vol. I, cit., pág. 339-342.
} 


\section{pontěditora}

necessário um tratamento igual de situações efectivamente iguais e um tratamento desigual de situações efectivamente desiguais. Quanto à proibição de discriminação (n. ${ }^{\circ}$, do artigo $\left.13 .^{\circ}\right)$, não exige um tratamento totalmente igualitário em todas as situações, nem se proíbe as diferenciações de tratamento. O que se proíbe são os factores de discriminações ilegítimos, previstos na Constituição, (no já referenciado n. ${ }^{\circ} 2$, do artigo $13^{\circ}$ ).

Assim, as medidas de diferenciação serão legítimas desde que: se baseiem em casos objectivamente e justificadamente distintos, não se fundamentem em nenhuma das situações mencionadas no n. $^{\circ} 2$, do artigo $13 .^{\circ}$, não contrariem a Constituição e se mostrem necessárias, adequadas e proporcionais à realização do objectivo que visam alcançar ${ }^{13}$. As decisões do Tribunal Constitucional (TC), continuam a assinalar correctamente, que o princípio da igualdade não impede a diferenciação de tratamento, mas apenas discriminações arbitrárias, irrazoáveis, sem justificação ou sem fundamentação material bastante ${ }^{14}$.

Por último, a obrigação de diferenciação, pretende compensar a desigualdade de oportunidades, aqui podemos ver claramente uma manifestação da função social deste princípio. Na realidade, não há violação do princípio da igualdade quando se verifica uma discriminação positiva (um benefício) a favor do mais débil, do mais frágil, do mais desprotegido, visto que está em consonância com o sistema jurídico-constitucional. Mais, no que respeita à função de protecção do princípio da igualdade, relativamente às discriminações positivas, ele constitui claramente uma imposição constitucional em nome da igualdade de oportunidade, por exemplo, n. ${ }^{\circ} 3$ do $\operatorname{artigo} 68^{\circ}$, n. $^{\circ} 2$ do artigo $69 .^{\circ}$ e n..$^{\circ} 1$ do artigo $70 .^{\circ}$, (todos da CRP).

\subsection{O princípio da igualdade e o artigo $266^{\circ}$ da CRP}

Todas as funções estaduais estão vinculadas ao princípio material da igualdade. "O princípio da igualdade repercute-se nos actos legislativos, vedando o arbítrio do legislador, e nos actos administrativos e judiciais, em relação aos quais prescreve a unidade na aplicação do direito

\footnotetext{
13 Gomes Canotilho e Vital Moreira, "Constituição Anotada", Vol.l, cit., pág. 340.

${ }^{14}$ Vide, por exemplo Acórdão do TC n. ${ }^{\circ} 80 / 86$, Proc. n. ${ }^{\circ}$ 148/84, publicado no D.R. n. ${ }^{\circ} 131$, de 09/06/86, I Série, págs. 1366 a 1373.
} 


\section{pontěditora}

feita pela Administração e pelos tribunais"15.

No que concerne, especificamente, à Administração Pública, prescreve o n. ${ }^{\circ} 2$ do artigo 266. ${ }^{\circ}$ da CRP, “[o]s órgãos e agentes administrativos estão subordinados à Constituição e à lei e devem actuar, no exercício das suas funções, com respeito pelos princípios da igualdade, da proporcionalidade, da justiça e da imparcialidade”. Pretende-se aqui salientar a vinculação administrativa às normas e aos princípios constitucionais, designadamente ao princípio da igualdade, incluindo a proibição do arbítrio e da discriminação. Assim, o princípio da igualdade (n. ${ }^{\circ} 2,2^{\circ}$ parte) é nesta sede, um reflexo do princípio jurídico geral da igualdade consagrada no artigo $13{ }^{\circ}$ Este princípio postula que se dê tratamento igual a situações de facto essencialmente iguais e tratamento diverso a situações de facto desiguais ${ }^{16}$.

\section{O princípio da igualdade na doutrina e no código do procedimento administrativo (CPA)}

\subsection{Evolução da compreensão do princípio da igualdade}

A compreensão do princípio da igualdade enunciado, como vimos, primeiramente, em França, na Declaração de Direitos do Homem e do Cidadão, de 1793, não foi sempre a mesma. O entendimento que se tem deste princípio passou por três fases essenciais ${ }^{17}$.

Numa primeira fase, o princípio da igualdade confunde-se com o princípio da prevalência da lei. Na época liberal, em que o Direito se resumia à lei (positivismo jurídico), o princípio da igualdade, surgia-nos como um valor absoluto, e sem reservas, o que o conduzia a um princípio meramente formal. Assim, nesta fase ser considerado igual perante uma lei, que era geral e abstracta, significa ser destinatário da aplicação dessa lei.

Esta ideia de igualdade formal, na prática levava a desigualdades, pelo que houve necessidade

\footnotetext{
${ }^{15}$ Maria Aline Gago da Silva e Jorge Baptista Bruxo, “Princípios Jurídicos da Administração Pública”, Imprensa Nacional - Casa da Moeda, 1985, pág.14.

${ }^{16}$ J.J. Gomes Canotilho e Vital Moreira, “Constituição da República Portuguesa Anotada”, 3. Edição Revista, Coimbra Editora, 1993, anotação ao artigo 266, pág. 924 e José Carlos Vieira de Andrade, “Os Direitos Fundamentais na Constituição Portuguesa de 1976", 3. . Edição, Almedina, 2004, pág. 240.

${ }^{17}$ Maria Glória Garcia, “Estudos sobre o Princípio”, cit., pág. 29-70
} 


\section{pontěditora}

de um alargamento desta compreensão do princípio.

Entramos numa segunda fase, em que o princípio da igualdade é entendido essencialmente como proibição do arbítrio. Há um apelo a critérios materiais de qualificação da igualdade, entendida em termos relativos, o princípio surge-nos aqui, como uma exigência de critérios razoáveis e suficientes, proibindo o arbítrio, na determinação da igualdade em função de um certo tratamento jurídico. Assim, embora já tenha uma abertura relativa à ideia de justiça material, continua, no entanto, ainda a ser entendido em termos formais (pois não se exige, em termos concretos, que seja este critério, e não aquele outro critério, bastando que o critério escolhido não tenha sido adoptado arbitrariamente). Surge, aqui a igualdade como limite externo dos poderes públicos.

Por último, entramos na terceira fase, na qual se alia aos conteúdos adquiridos das fases anteriores um maior desejo de justiça, assim surge-nos o princípio de igualdade ligado ao próprio sentido de justiça. O princípio da igualdade adquire uma nova função, a da realização da justiça. Há que discriminar para igualar. Aparece então a igualdade como um limite interno da actuação dos poderes públicos.

Desta evolução da compreensão do princípio da igualdade, que passou por estas três fases essenciais, resultou o sentido unitário que hoje reconhecemos ao princípio da igualdade, (acrescenta a ideia social e democrática ao pensamento liberal). Por um lado, temos a igualdade normativa, preocupada com a justiça da aplicação da norma - igualdade de todos perante a lei, o que tendencialmente implica a generalidade da norma -, ao lado uma igualdade jurídicopolítica angustiada com o critério material de qualificação igual para efeitos de tratamento jurídico, por outro lado, inquieta com a intencionalidade da norma - igualdade da própria lei. Critério e intencionalidade, que por sua vez se encontram ligados com o processo formativo de valores que lhes presidem - igualdade para o direito.

É este entendimento alargado do princípio da igualdade que nos oferece uma maior confiança nas suas grandes potencialidades, na luta contra as injustiças.

\subsection{O princípio da igualdade e o $\mathbf{n}^{\circ} 1$, do artigo $6^{\circ}$, do CPA}

São princípios importantes para a actividade administrativa, para além do princípio da igualdade, designadamente, o da legalidade, da imparcialidade, da justiça, da proporcionalidade, da protecção da confiança, da boa fé, da racionalidade, que são todos 


\section{pontěditora}

princípios da juridicidade substancial, explicitados na Constituição e na lei. ${ }^{18}$.

Quanto ao princípio da igualdade está consagrado no n. $^{\circ} 1$, do artigo $6^{\circ}$ (corresponde ao artigo 5. do anterior Código), do CPA, que o prevê em termos gerais, "[n] as suas relações com os particulares, a Administração pública deve reger-se pelo principio da igualdade, não podendo privilegiar, beneficiar, prejudicar, privar de qualquer direito ou isentar de qualquer dever nenhum administrado em razão de ascendência, sexo, raça, língua, território de origem, religião, convicções politicas ou ideológicas, instrução, situação económica ou condição social ou orientação sexual”.

O princípio da igualdade decorre do princípio de justiça (previsto no n. ${ }^{\circ} 2$ do artigo $266 .^{\circ}$ da CRP e no artigo $8 .^{\circ}$ (antigo artigo $6 .^{\circ}$ ) do CPA, pretende dar a cada um o que lhe é devido. Para o princípio da igualdade, numa formulação clássica, situações iguais devem ter um tratamento igual, situações entre si diferentes devem ter um tratamento diferente, na medida dessa diferença.

Mas a igualdade ou desigualdade das situações da vida não têm de ser absolutas, têm é de se verificar nos aspectos que se afigurem relevantes à luz do poder administrativo concretamente exercido e do fim para o qual ele foi legalmente concedido, assim a igualdade ou diferença não são puramente fácticas, mas de qualificação jurídica.

Uma vez feita a qualificação jurídica entre situações, o princípio da igualdade num sentido negativo, implica que se não trate desigualmente o que deve ser igual, impondo à administração o dever de não agir de modo a introduzir desigualdades e num sentido positivo, implica que se trate de modo igual o que deve ser igual, impondo à administração o dever de agir no sentido de corrigir ou evitar desigualdades.

Quanto ao conteúdo da conduta que a Administração deve adoptar, distingue-se entre situações de proibição de discriminação e obrigação de discriminação, (para mais desenvolvimentos, ponto 2.1, deste artigo).

A proibição de discriminação tolhe toda a discriminação inaceitável, quer a que se reflecte em tratar de modo desigual o que deve ser igual, quer a tratar de modo igual o que é desigual, assim tanto se exige à Administração um dever de agir (tratando igualmente o que deve ser igual e impedindo que se trate desigualmente o que é igual), como se exige um dever de não agir (não introduzindo desigualdades no que deve ser igual ou introduzindo igualdades no que deve ser desigual). Quanto à obrigação de diferenciação subordina-se à ideia de introduzir tantas

${ }^{18}$ José Carlos Vieira de Andrade, “A Justiça Administrativa, (Lições)”, 7. ․ Edição, Almedina, 2005, pág. 445.

$\mathbf{J}^{2}$ - Jornal Jurídico | Volume 1 | Número 1 


\section{pontéditora}

diferenciações quantas as necessárias para alcançar a igualdade substancial, quer tratando o desigualmente o que é igual e deve ser desigual, quer tratando desigualmente que é desigual e deve ser igual (discriminação positiva); aqui a Administração tem sempre dever de agir ${ }^{19}$.

\subsubsection{O princípio da igualdade como limite imanente da margem de livre decisão (do poder discricionário)}

Surgem-nos como limites imanentes do poder discricionários os princípios jurídicos da actividade administrativa previstos no.$^{\circ} 1$ e n. 2 do $\operatorname{artigo} 266 .^{\circ}$, da CRP, e $\operatorname{artigo~} 3 .^{\circ}$ a $19 .^{\circ}$ do (novo) CPA. Entre eles inclui-se o princípio da igualdade. Estes princípios são limites de todas as condutas administrativas e não apenas das adoptadas no uso de poderes discricionários ${ }^{20}$, mas a sua violação por condutas administrativas vinculada não releva

\footnotetext{
${ }^{19}$ Neste ponto do trabalho, (3.2), seguimos de perto a obra, Marcelo Rebelo de Sousa e André Salgado Matos, "Direito Administrativo Geral: Introdução e Princípios Fundamentais", Tomo I, 2. Edição, Dom Quixote, 2006, pág. 222-223.

${ }^{20} \mathrm{~A}$ lei define sempre os fins e as competências do acto administrativo a praticar, quanto ao conteúdo é que pode dar uma margem de livre decisão à Administração. Assim, podemos ter actos de conteúdo vinculado ou actos de conteúdo discricionário.
}

A Discricionariedade é assim, uma concessão legislativa à Administração de um poder próprio na decisão de casos concretos (ou seja, um poder que lhe é concedido para que a Administração encontre aquela que considere ser a melhor solução para o caso concreto, que obviamente, só pode vir a ser uma.). Toda a actividade administrativa, mesmo ao abrigo de poderes discricionários, está hoje subordinada ao Direito, é jurídica, do ponto de vista funcional (porque visa encontrar a melhor solução para a realização do interesse publico legalmente definido), quer do ponto de vista substancial (está sujeita a princípios jurídicos, como o da boa fé, da imparcialidade, da igualdade e da proporcionalidade, que ao lhe fornecerem parâmetros da decisão, se mostram, deste modo, como limites da decisão administrativa discricionária). Nesta medida estão sujeita a uma físcalização jurisdicional.

Assim, o critério de controlo que é feito pelos tribunais, quando administração actua ao abrigo de poderes discricionários, é mais vago, sendo constituído pelos princípios jurídicos, que como já vimos, norteiam e limitação a actuação da administração. Mas os tribunais já não apreciam do mérito da decisão da administração, sob pena de praticarem uma "dupla administração". Isto mesmo, nos refere expressamente, n. ${ }^{\circ} 1$, do artigo $3 .^{\circ}$ do Código do Processo dos Tribunais Administrativos (CPTA), “[n]o respeito pelo principio da separação de poderes e interdependência de poderes, os tribunais administrativos julgam do cumprimento pela Administração das normas e princípios jurídicos que a vinculam e não da conveniência ou oportunidade da sua actuação". O mérito das decisões administrativas engloba a apreciação de oportunidade (utilidade da concreta actuação administrativa para 


\section{pontěditora}

autonomamente, no caso de actos vinculados a Administração tem apenas de cumprir a lei, sob pena de praticar um acto ilegal ${ }^{21}$.

Nestes termos, o princípio da igualdade, como aliás todos os outros princípios jurídicos da actividade administrativa, só é fonte autónoma de invalidade no âmbito do uso de poderes discricionários da Administração.

\subsubsection{Autovinculação (casuística) da Administração no âmbito dos seus poderes discricionários}

Estando a actuar ao abrigo de poderes discricionários, reserva-se uma referência especial à ideia de autovinculação da administração, (regra do precedente), que se traduz na utilização de critérios substancialmente semelhantes para a resolução de casos semelhantes, traduzindo-se numa violação do princípio da igualdade uma mudança de critérios, sem qualquer fundamentação material: a Administração só pode afastar-se de uma prática anterior, que não seja ilegal (por não existir um direito à igualdade na ilegalidade), se ocorrerem alterações na "dimensão do interesse público prosseguido ou dos interesses particulares com ele comprometidos" 22 .

No entanto para que se possa falar em regra do precedente é necessário que se cumpram requisitos positivos e negativos ${ }^{23}$.

São requisitos positivos, a identidade subjectiva, as actuações têm de (a anterior e a actual) provir do meu órgão ou dos seus sucessores legais nessa competência, tem de haver também identidade objectiva - os elementos objectivos das situações concretas (pressupostos, procedimento e forma) têm de ser idênticos, por fim exige-se identidade normativa das situações em análise, identidade da disciplina jurídica.

Como requisito negativo diga-se que a precedente decisão da administração não pode ser ilegal,

\footnotetext{
a prossecução do interesse publico legalmente definido) e da conveniência (utilidade da concreta actuação administrativa para a prossecução do interesse publico legalmente definido à luz dos demais interesses públicos envolvidos). Vide Vieira de Andrade, “A Justiça Administrativa”, cit., pág. 94-98.

${ }^{21}$ Marcelo de Sousa e André Matos, "Princípios Fundamentais", cit., pág. 201.

${ }^{22}$ Mário de Oliveira, Pedro Gonçalves e João Amorim, “Código do Procedimento Administrativo”, cit., pág. 100.

${ }^{23}$ Idem, pág. 101.
} 


\section{pontěditora}

não há "direito à igualdade na ilegalidade" - a jurisprudência tem vindo a ser unânime nesta conclusão.

\subsubsection{Limites à regra do precedente da actuação administrativa}

Por um lado, as vantagens que decorrem da autovinculação são evidentes, permitem aumentar a segurança, a previsibilidade e a certeza que podem decorrer da margem de livre decisão administrativa, por outro lado ao darem critérios de soluções acabados à Administração retiramlhe a necessidade da elaboração de juízos que podem vir a revelar-se complexos, constituindo assim um factor de desburocratização e celeridade das decisões administrativas ${ }^{24}$. No entanto, nem tudo são vantagens, não podem pois deixar de se apontar algumas desvantagens à autovinculação da Administração, assim admitir-se “a autovinculação da administração à decisão precedente não significa o reconhecimento da vinculatividade "das directivas de discricionariedade", actos internos tendentes ao estabelecimento de critérios de aplicação uniforme da lei”. Até porque a lei que concede poderes discricionários à Administração implica uma proibição de desatender às circunstâncias do caso concreto, pelo que não pode uma "norma interna" vir transformar em vinculado um poder que a norma de competência quis que fosse discricionário ${ }^{25}$.

A este propósito, Marcelo Rebelo de Sousa e André Salgado Matos falam em limites à autovinculação da Administração. Primeiro, ao critérios decisórios que dela resultam não podem ser imutáveis, petrificados, porque em nome do poder discricionário tem de se admitir que quando for juridicamente necessário, ou apenas oportuno ou conveniente, possam ser revistos pela Administração, ou seja é necessário que possa existir uma autodesvinculação. Segundo, a autovinculação não dispensa o decisor administrativo de verificar se no caso concreto existem circunstâncias que exijam uma diferente ponderação dos interesses envolvidos; se tal acontecer o caso deve ser tido como atípico, (ou seja, saindo fora do âmbito da autovinculação) e como tal deve ser decidido sem recurso aos critérios pré-determinados ${ }^{26}$. Defendem também os citados autores, que os actos jurídicos que contém decisões de autovinculação apresentam uma natureza normativa, pois contém regras de conduta que se

\footnotetext{
${ }^{24}$ Marcelo de Sousa e André Matos, "Princípios Fundamentais”, cit. pág. 196.

${ }^{25}$ Mário de Oliveira, Pedro Gonçalves e João Amorim, “Código do Procedimento Administrativo", cit. pág. 101 e 102.

${ }^{26}$ Marcelo de Sousa e André Matos, "Princípios Fundamentais”, cit. pág. 196.
} 


\section{pontěditora}

destinam a ser aplicadas a um número indeterminável de casos. No entanto, tais normas não têm eficácia externa, devido à possibilidade de no caso concreto serem afastadas e à reduzida vinculatividade que daí decorre ${ }^{27}$.

Também não deve exigir-se que a Administração anuncie antecipadamente a mudança dos seus critérios gerais e abstractos pré-determinados, pois pode acontecer que só se aperceba da necessidade, ou mérito (oportunidade ou conveniência) de tal mudança, precisamente aquando da decisão de um caso concreto. Assim, a mudança do critério decisório, bem como a não aplicação das instruções da autovinculação em casos atípicos, gera apenas a obrigação da correspondente fundamentação material específica, o que decorre da al. d) do n. ${ }^{\circ} 1$ do artigo 152. ${ }^{\circ}$, do (novo) CPA, há o dever de fundamentação dos actos administrativos que, "decidam de modo diferente da prática habitualmente seguida na resolução de casos semelhantes (...)".28

Nestes termos, o princípio da igualdade não proíbe a diversidade de tratamento, o que se veda é a "proibição de discriminações e segregações arbitrárias ou injustificadas", (ou seja "o estabelecimento de distinções sem fundamento racional e objectivo, ditadas pela irrazoabilidade e, pelo mero arbítrio”). O que importa “(...) é que não se discrimine para discriminar"29.

\subsubsection{A relevância prática do princípio da igualdade}

Retomando as palavras por nós usadas na introdução deste ensaio, o princípio da igualdade é teoricamente complexo e da aplicação prática extremamente difícil. Vamos tentar perceber porque esta concretização prática se afigura complicada ${ }^{30}$.

Invalidar uma actuação administrativa com base na violação do princípio da igualdade depende de dois pressupostos: a igualdade ou diferença entre duas situações da vida e entre os tratamentos que lhes foram dispensados. Este princípio como parâmetro de controlo da actividade discricionária da administração conta com uma operatividade limitada, isto é assim

\footnotetext{
27 Idem, pág.197.

${ }^{28}$ Ibidem, pág. 197.

${ }^{29}$ Vieira de Andrade, “Os Direitos Fundamentais na Constituição”, cit., pág. 280 e 311 e Acórdão do STA, Proc, n. ${ }^{\circ} 047525$, de $29 / 01 / 2002$.

${ }^{30}$ Marcelo de Sousa e André Matos, "Princípios Fundamentais”, cit., pág.224.
} 


\section{pontěditora}

porque: a actividade administrativa não sendo secreta, (podendo quem pretender fazer uso do direito fundamental à informação, n. ${ }^{\circ} 1$ do artigo $268^{\circ}$, da CRP e artigo $17 .^{\circ}$ e $82 .^{\circ}$ do novo CPA, e em geral, do princípio da colaboração da Administração com particulares, artigo 11. ${ }^{\circ}$ do novo CPA), conta com uma publicidade limitada, e por isso não será fácil a quem tenha sido objecto de tratamento desigual demonstrá-lo em tribunal, ou mesmo, conhecer as situações similares à sua, que tiveram um tratamento diferente por parte da administração. Para além disto, é praticamente impossível encontrar duas situações da vida absolutamente idênticas, pelo que se afigura também complicado demonstrar que possíveis desigualdades no tratamento pela administração não ocorreram por diferenças das situações.

A relevância prática do princípio da igualdade aumenta consideravelmente enquanto parâmetro de controlo do poder discricionário da administração perante discriminações ocorridas no âmbito do mesmo contexto procedimental (por exemplo, relativos a dois concorrentes do mesmo concurso público).

Também, neste sentido, Rui Medeiros e Jorge Miranda, “[o] princípio da igualdade tem uma especial relevância prática no que respeita aos concursos de acesso à função pública ou de classificação e promoção a cargos e categorias da função pública. O princípio vale também para a retribuição dos funcionários públicos. Vale para os funcionários, o princípio "igual trabalho, igual salário"31

Não é por acaso que grande parte das decisões dos tribunais administrativos de anulação de acto administrativos, por violação do princípio da igualdade ocorre no âmbito de concursos públicos $^{32}$.

\section{Conclusão}

O princípio da igualdade tem consagração constitucional em Portugal desde as Constituições Monárquicas do séc. XIX. Este princípio, tal como hoje o conhecemos, é o resultado de uma grande evolução a que esteve sujeito ao longo de quase dois séculos de existência.

Tem consagração na actual Constituição Portuguesa, (de 1976), no artigo $13^{\circ}$ e especificamente, quanto à actividade administrativa, no n. 2 do artigo 266. ${ }^{\circ}$. No Código do Procedimento

\footnotetext{
${ }^{31}$ Rui Medeiros e Jorge Miranda, “Constituição Portuguesa Anotada”, Tomo III, Coimbra Editora, 2007, anotação ao artigo $266^{\circ}$, pág. 570 .

${ }^{32}$ Marcelo de Sousa e André Matos, "Princípios Fundamentais", cit., pág. 224
} 


\section{pontěditora}

Administrativo está previsto actualmente no n. ${ }^{\circ} 1$ do artigo $6 .^{\circ}$ (corresponde ao artigo $5 .^{\circ}$ do anterior CPA).

É um princípio importante ligado com a própria dignidade humana, que decorre do princípio de justiça, é teoricamente elaborado e na prática de difícil concretização.

Surge-nos ao lado de outros princípios jurídicos, como limite imanente da margem de livre decisão (discricionariedade) da Administração, relevando só neste âmbito como fonte autónoma de invalidade dos actos administrativos.

Implica que se trate o que igual de modo igual, e o que é desigual de modo desigual, na medida dessa diferença.

É um princípio relacional, uma vez que se vai comparar o critério decisório que a Administração adoptou em relação a um "caso precedente”, para depois se houver identidade normativa, subjectiva e objectiva, o aplicar ao "caso posterior", é a "regra do precedente" ou autovinculação da Administração.

No entanto, a autovinvulação administrativa encontra importantes limites, deste modo só porque existe uma pré-determinação para que a Administração possa agir num determinado sentido, não pode nunca deixar de analisar as circunstâncias do caso concreto, que podem justificar o abandono da regra do precedente, sob pena de comprometer a norma de competência que lhe atribuiu poderes discricionários naquela matéria.

Nestes termos, a Administração não está obrigada a uma igualdade de tratamento, o que se veda é a mudança de critérios em relação a casos iguais, sem fundamentação material legítima, ou seja o que se proíbe é o arbítrio das decisões administrativas.

Na prática encontra vários obstáculos à sua aplicação, quem sofreu um tratamento violador do princípio da igualdade muitas vezes não consegue demonstrar, nem conhece as situações iguais à sua que tiveram um tratamento desigual pela Administração. Até porque é praticamente impossível ter duas situações absolutamente iguais, tornando-se difícil provar que a discriminação não surgiu devido a essas diferenças.

Estas dificuldades são superadas no âmbito de um mesmo contexto procedimental (como por ex. concursos públicos), onde o princípio tem grande operatividade. Não é por acaso que a grande parte das decisões do STA, que conduz à anulação de actos administrativos, por violação do princípio da igualdade ocorre no âmbito de concursos públicos.

Entendendo embora as razões que justificam a reduzida operatividade do princípio da igualdade, lamentamos no entanto que assim seja, pois sendo este um princípio estruturante do 


\section{pontěditora}

Estado de Direito Democrático e Social, ligado com a própria ideia de dignidade humana e com princípio de justiça achamos que devia ter uma maior relevância prática!

\section{Bibliografia}

ALBUQUERQUE, Martim, “Da Igualdade - Introdução à Jurisprudência”, Livraria Almedina, Coimbra, 2003.

ANDRADE, José Carlos Vieira de, “Os Direitos Fundamentais na Constituição Portuguesa de 1976", 3. ․ Edição, Almedina, 2004.

ANDRADE, José Carlos Vieira de, “A Justiça Administrativa, (Lições) ”, 7. ${ }^{\circ}$ Edição, Almedina, 2005.

BRUXO, Jorge Baptista/ SILVA, Maria Aline Gago da, "Princípios Jurídicos da Administração Pública”, Imprensa Nacional - Casa da Moeda, 1985.

CANOTILHO, J.J. Gomes/ MOREIRA, Vital, "Constituição da Republica Portuguesa Anotada”, 3. . Edição Revista, Coimbra Editora, 1993.

CANOTILHO, J.J. Gomes Canotilho/ MOREIRA Vital, "Constituição da República Portuguesa Anotada”, Vol. I, 4. ${ }^{\circ}$ Edição Revista, 2007.

FRANCO, João Melo/ MARTINS, António Herlander Antunes, "Dicionário de Conceitos e Princípios Jurídicos: na Doutrina e na Jurisprudência", 3. Edição, Almedina, 1993.

GARCIA, Maria Glória F.P.D., “Estudos sobre o Princípio da Igualdade”, Almedina, 2005.

MEDEIROS, Rui/ MIRANDA, Jorge, “Constituição Portuguesa Anotada”, Tomo III, Coimbra Editora, 2007. 


\section{pontěditora}

NOVAIS, Jorge Reis, “Os Princípios Constitucionais Estruturantes da República Portuguesa”, Coimbra Editora, 2004.

OLIVEIRA, Mário Esteves de/ GONÇALVES, Pedro Costa/ AMORIM, João Pacheco, “Código do Procedimento Administrativo - comentado”, 2. Edição, Março de 2005.

SOUSA, Marcelo Rebelo de/ MATOS, André Salgado, "Direito Administrativo Geral: Introdução e Princípios Fundamentais”, Tomo I, 2. ${ }^{\circ}$ Edição, Dom Quixote, 2006

${ }^{1}$ Abreviaturas e siglas utilizadas: Ac.(s) - Acórdão(s); al.(s) - alínea(s); AI - Administrador da Insolvência; AJP - Administrador Judicial Provisório; $\operatorname{art.}^{\circ}(\mathrm{s})$ - $\operatorname{artigo(s);~cfr.~-~}$ conferir/confrontar; CC - Código Civil; CIRE - Código da Insolvência e da Recuperação de Empresas, aprovado pela Lei n. ${ }^{\circ}$ 53/2004, de 18 de Março; CPC - Código de Processo Civil, aprovado pela Lei n. ${ }^{\circ}$ 41/2013, de 26 de junho; CRP - Constituição da República Portuguesa; CT - Código do Trabalho, aprovado pela Lei n. ${ }^{\circ}$ 7/2009, de 12 de fevereiro; CT 2003 - Código do Trabalho, aprovado pela Lei n. ${ }^{\circ}$ 99/2003, de 27 de agosto; DL - Decreto-Lei; FGS - Fundo de Garantia Salarial; NRFGS - Novo Regime do Fundo de Garantia Salarial, aprovado pelo Decreto-Lei n. ${ }^{o}$ 59/2015, de 21 de abril; RCT - Regulamentação do Código do Trabalho, aprovada pela Lei n. ${ }^{\circ}$ 35/2004, de 29 de Julho; n. ${ }^{\circ}(\mathrm{s})$ - número(s); PER - Processo Especial de Revitalização, introduzido no CIRE, dos artigos 17..$^{\circ}$-A a 17. ${ }^{\circ}-H$, pela Lei n. ${ }^{\circ}$ 16/2012, de 20 de abril; TAF - Tribunal Administrativo e Fiscal; TCA-Norte - Tribunal Central Administrativo Norte; TCA-Sul - Tribunal Central Administrativo Sul; TJ - Tribunal de Justiça das Comunidades Europeias/Tribunal de Justiça da União Europeia.

$\mathbf{J}^{2}$ - Jornal Jurídico | Volume 1 | Número 1 